\title{
Environment and society: the Sinos River Basin and public policies
}

\author{
Pedde, V. ${ }^{\text {** }}$, Figueiredo, JAS ${ }^{a}$, Nunes, MF ${ }^{a}$ and Prodanov, CC. ${ }^{a}$ \\ ${ }^{a}$ Universidade Feevale, Estrada RS-239, 2755, CEP 93352-000, Novo Hamburgo, RS, Brazil \\ *e-mail: valpe@feevale.br
}

Received: May 24, 2013 - Accepted: July 28, 2013 - Distributed: May 31, 2015

(With 4 figures)

\begin{abstract}
This study discusses the tensions and conflicts in the relationship between environment and society in the Sinos River Basin, in the state of Rio Grande do Sul, Brazil. An environmental disaster in 2006, which resulted in the death of 100 tons of fish in the Sinos River, is the dividing line for this study. A review of documents and field interviews with representatives of the municipal government and companies in the region were used to analyze the impact of public policies on the environment and which deficiencies remain ${ }^{1}$.
\end{abstract}

Keywords: Sinos River Basin, public policies, environmental impact.

\section{Meio Ambiente e sociedade: a Bacia do Rio dos Sinos e políticas públicas}

\section{Resumo}

Este estudo discute as tensões e conflitos na relação entre meio ambiente e sociedade na Bacia do Rio dos Sinos, no estado do Rio Grande do Sul, Brasil. Um desastre ambiental ocorrido em 2006, o qual resultou na morte de 100 toneladas de peixes no Rio dos Sinos, é a linha divisória para este estudo. Uma análise de documentos e entrevistas de campo com representantes do governo municipal e empresas da região foram usados para analisar o impacto das políticas públicas sobre o meio ambiente e quais deficiências permanecem.

Palavras chave: Bacia do Rio dos Sinos, políticas públicas, impacto ambiental.

\section{Brief History of the Sinos Valley}

Until the middle of the XIX century, the region known today as the Sinos Valley was inhabited by "[...] residents in nobody's land, who planted their crops there" and who "did not have land titles" (Porto, 1934, p. 18) and by sesmeiros, holders of titles to allotments of uncultivated land (sesmarias), particularly Portuguese and Azorean settlers and their descendents. Since the XVIII century, the region was also home to the Royal Flax Trading Post (Real Feitoria do Linho Cânhamo), transferred from Canguçu to produce cordage using slave labor (Nunes, 2009).

After the Independence of Brazil in 1822, other interests came into play. The Flax Trading Post declined because of the needs of the recently-proclaimed Brazilian Empire and the new "vocations" defined for the region.

\footnotetext{
We thank Malcon Naor Voltz and Ana Arnoldo, undergraduate research grant holders, for their participation in data collection for this study.

2 Located in the southernmost region of Brazil, in the Pelotas microregion and the southeastern mesoregion, according to the classifications used by the Economy and Statistics Foundation of Rio Grande do Sul (FEE/RS - Fundação de Economia e Estatística do Rio Grande do Sul) (Rio Grande do Sul, 2012b).
}

The country borders had to be defended, and for that purpose there should be people, in addition to the army, to occupy regions of conflict and provide logistic support to imperial troops. Settlers were necessary. Moreover, after the antislavery insurrections in Haiti, which led to the elimination of the white minority in that country, the white elite believed that the population had to be "whitened". The British Empire, at the same time, was urging Brazil to end slavery (Dreher, 1989). Liberal illuminist ideas spread, and an important modernizing role was identified in Protestantism (Mendonça and Velasques Filho, 1990).

Starting in 1824, German settlers, encouraged by the Brazilian Empire, started to arrive, despite the resistance of populations already settled in the area and the opposition of traditional indigenous societies. In that year, a group of 39 German settlers in search of lands disembarked in the place known as the Flax Trading Post (Feitoria do Linho Cânhamo), in what is today the city of São Leopoldo ${ }^{3}$.

\footnotetext{
3 In the first eleven groups of immigrants that arrived between 1824 and 1825 , there were 1027 people. In the first group of immigrants, on June 25, 1824, there were 39 people and, in the last group, on December 31, 1825, 147 people. (Hunsche, 1975).
} 
Records show that, in 1829 , there were nine tanners ${ }^{4}$ in the region of the Sinos Valley, which confirms that development in the Sinos Valley originated with tanning. Industrialization followed the history of tanneries and the manufacturers of saddles and bridles. Using leather scraps, they started the production of sandals, and soon boots and shoes were being manufactured as well, but only to supply the local market. The demand for boots increased with the beginning of the Paraguayan War (1864-1870), because soldiers needed sturdy footwear. As the demand for those products increased significantly, the market had to expand and seek new, less amateurish technologies.

With the arrival of German settlers, the work that used to be performed by slaves acquired a new status and was performed by a new agent: German immigrants, who represented "free labor" decades before the abolition of slavery. Slaves, however, retained the technique to manufacture leather utensils and artifacts based on the work carried out in the meat salting and drying shops (charqueadas), which contributed to explain the concentration of black workers in the Sinos Valley tannery industry in its initial phase of industrialization, in the middle of the XX century ${ }^{5}$.

Gradually, the artisanal and manufacturing techniques solidified the basis of one of the most industrialized regions of the state of Rio Grande do Sul. The consequence was the use of the waters of the Sinos River Basin, as well as its intense and gradual exploration, which triggered social and environmental problems that worsened along time.

The leather and footwear sector has major importance, not only for the region where it is installed, but also for all the economy of the state of Rio Grande do Sul and of Brazil. In the beginning of the XXI century, it remains one of the most dynamic sectors of the regional economy due to its intensive use of labor, the income that it generates and the productive chains that are associated with the direct and indirect support to this sector.

Leather and footwear manufacturing began its development in the Sinos Valley in the end of the XIX century. Until the mid 1960 s, all production was meant for the internal market, but, from that decade on, exportations began to Europe and the United States. In the following decades, the sector reached its economic climax, as well as its expansion and consolidation as a complex and complete chain. Such consolidation was called a cluster, because companies were connected to each other in close collaboration and forming a supply chain, existing in a certain restricted area, limited by some of the Sinos Valley towns. The concept of a leather and footwear cluster, important to say, defines the productive concentration and clustering of companies in this industrial activity sector, as well as of correlated organizations, and includes suppliers, educational organizations and clients (Porter, 1989).

\footnotetext{
4 Further information can be found in Costa and Passos (2004).

5 Margarete Fagundes Nunes has conducted studies about the importance of black workers in the tanning industry in the Sinos Valley, particularly in the first half of the XX century, in the project The black communities in the Sinos Valley and Labor Memory (Nunes et al., 2013).
}

Such industrial concentration has led to changes in urban and industrial structures, as well as in the relations between human beings, their activities and environment. Their balance has been gradually affected by greater concentrations of people and industrial activities without any form or effluent control or treatment by the government.

As seen before, the 1960s brought the increase in the number of leather and footwear manufacturers, which reached out to the external market and generated more jobs. In consequence, the Sinos Valley population increased as more and more workers migrated to the region in search of opportunities. The main objective of the municipal government was to promote production and wealth, and there was little ecological awareness and determination to preserve the environment. Therefore, those migrants moved to the margins of crooks and public areas, and the residues of what was produced were disposed of in the nature without any criteria. The population grew, their needs increased, and raw materials had to be used to respond to them. As resources were explored, residues were discarded in the river. The Sinos Valley disorganized growth is confirmed by a civil servant, who reported that:

[...] There was illegal occupation of the city, influenced by the municipal government itself. Let us not blame one party or the other. Both the city hall and the city council. Not the city council as an institution, but as politicians, the councilmen of the time found, in the city hall, which places were public areas, and then said: "build your little house there, build it there, build your house there." And the city hall itself also sometimes was not prepared and did not expect that flow, and therefore had to look the other way and had no conditions to control the occupation of those areas, which took place spontaneously in some cases and in an organized way in others. And it is interesting that Novo Hamburgo... we spent the 1990s, when we started to study more and to attack and further develop the occupation policies, Novo Hamburgo was seen as two cities, the formal city and the informal city, the legal city and the illegal city. The formal city is the one formed by the legal city, which has an urban master plan, follows the city code, all those things. And informal is the city that formed according to the needs of those people that came here to work, and this working space that actually did not made it possible, they were not destitute, or extremely poor, but did not have access to it, either due to a lack of market, of a product that could be paid by their wages - and I am not sure whether they would be able to pay for it - as the structure of a city is formed, as we have seen in Brazil, in other metropolitan areas. It is no privilege of Novo Hamburgo, and other cities developed in the same way too. Now, in terms of space, it was formed in the public areas. This informal city was created exactly in the area that was public: parks, streets, roadsides, the creek margins, principally (civil servant in the Housing Department).

As a consequence of the rapid degradation of the Sinos River and of a growing worldwide concern about the environment, especially in the 1970s and 1980s, some nongovernmental organizations (NGO) concerned with the environment in the region of the Sinos Valley came into play. Many of these environmental organizations were 
especially concerned with water resources. Because of these demands, the state of Rio Grande do Sul defined pollution control and inspection offices for the Guaíba, Gravataí and Sinos River Basins.

The first of these organizations was created in 1987 as a result of the SOS Sinos River campaign, conducted by ecological groups in the region. This movement had its climax in a conference held in September of that same year in the city of São Leopoldo, when a committee for the management of the waters in the Sinos River Basin was created. As a result of this movement, led mostly by NGOs, the Sinos Committee was created by governmental decree in 1988. It was the first river basin management committee created in Brazil (Cánepa and Grassi, 2001).

However, the catastrophe of tons of fish dying in 2006, together with the constant draughts in the summers of the last ten years, led to the conclusion that the movements of the 1980s and 1990s were not enough to stop the destruction of the Sinos River, as not all participants were equally committed. Moreover, the population, businesspeople and the government in the Sinos Valley were not yet prepared to understand that the river should provide to all those that live in its surroundings. Until that is clear to all, such situations seem to be difficult to deal with. Of the inhabitants in the Sinos Valley, 74.89\% need the river for their survival (IHU, 2012).

The 2006 environmental crime, considered the greatest environmental disaster of the last 40 years in the state of Rio Grande do Sul, caused the death of over one million fish along the river, generated commotion and outrage, and resulted in the immediate mobilization of the counties in the Basin area. Such effort resulted in the creation of the Pro-Sinos, an association of counties in the region that today has the participation of 22 cities and whose purpose is the environmental recovery of the Sinos River Basin. Below we discuss the role played by Pro-Sinos in further detail.

\section{Environmental Fragility of the Sinos River}

Currently, the Sinos River experiences a process of alarming agony. Therefore, to begin this topic, we use the words of an environment geologist, Arno Kayser:

If we consider that, according to geologists, the Sinos River is 110 million years old, as it was created during the separation of Africa and America and the magma movements on the planet surface, and that since then it has existed and survived the environment and its changes, running about 190 kilometers from a level of $600 \mathrm{~m}$ to 5 $\mathrm{m}$ above sea level. But after 1824, that is, less than 200 years ago, what began with a group of 39 people has hurt and destroyed it to the point that it is now $65 \mathrm{~cm}$ deep and its water is not appropriate for consumption by any animal and has to undergo extreme treatment procedures so that the population can drink the same water where they dispose of their waste (Kayser, 2011).

The Sinos River is an environmental reference in the region, a symbol of life for a society that depends on it to supply the cities that surround it and to ensure the survival of several species that insist on living there ${ }^{6}$.

The main problems diagnosed in the Sinos River result from the elimination of riparian vegetation and, consequently, of marshes and swamps, as well as of sand removal, margin erosion and use of water to flood rice fields ${ }^{7}$.

These problems, especially in summer, make the river reach critical water levels. This is evident when, in a brief survey, we confirmed that, from 2005 to 2012, there was only one high-water event. In the other years, draughts prevailed. In addition to that, in 2008 the river depth reached its lowest level in history: $45 \mathrm{~cm}^{8}$ (Jornal VS, 2012).

The difficulty associated with quantity is compounded with the problem of quality. According to the Brazilian Environment Council (CONAMA, Conselho Nacional do Meio Ambiente) (Brasil, 2012a) and the Municipal Water Distribution and Sewage Collection Department (COMUSA, Companhia Municipal de Saneamento) of Novo Hamburgo (Novo Hamburgo, 2012), the best water oxygenation conditions are found in the parts of the river where there are no large concentrations of people or factories. At the same time, where these two variables are found, there is also an alarming concentration of both fecal residues and heavy metals (Rio Grande do Sul, 2012a).

Therefore, the sum of lack of industrial effluent treatment, deficient urban sanitation and lack of environmental education are some of the main causes of a decrease in the quality and quantity of water of the Sinos River.

The Table 1 below shows that most polluting companies are located in the large urban centers, which generates a concentrated load of pollution in the regions of the middle and lower regions of the basin.

Finally, both the government and private companies are directly responsible for the serious condition of the Sinos River. In general, municipal policy making in the area of environmental protection lacks a more active popular participation and tends to be structured rather by market demands and the pressure of means of communications that seem to adopt a more sensationalist, rather than reflexive, view.

\footnotetext{
6 The text used as the basis to build this topic was first written for the Doctoral Thesis of João Alcione Sganderla Figueiredo (Figueiredo, 2008), whose main references were the information found in the following organizations: SOS Rio do Sinos, Instituição Martin Pescador, FEPAM, COMUSA, SEMAE, CORSAN and municipal environment departments.

7 In addition to removing water illegally, they use engines that leak fuel and oil and contaminate the river. Therefore, a dual environmental crime.

8 In Figure 1 we observe the removal of sand from the river bottom and in Figure 2 we observe the removal of rice irrigation water, at the same time that it pollutes the river with oil from the engine. In Figures 3 and 4 we registered dry periods in Sinos River.
} 
Table 1. Association between economic activity and environmental risk in the Sinos River Basin.

\begin{tabular}{|c|c|c|}
\hline Part of the Basin & Economic activity & Environmental Risk \\
\hline Upper & $\begin{array}{l}\text { Agriculture and dairy cattle in small farms, } \\
\text { and rice fields }\end{array}$ & $\begin{array}{c}\text { Low } \\
\text { (household effluents and PPA occupation by } \\
\text { rural activities }\end{array}$ \\
\hline Middle (mountains) & $\begin{array}{l}\text { Logging, furniture, tourism, hotels and } \\
\text { commercial industry }\end{array}$ & $\begin{array}{c}\text { Moderate } \\
\text { (household and industrial effluents and PPA } \\
\text { occupation by urban area) }\end{array}$ \\
\hline Middle (valley) & $\begin{array}{l}\text { Leather and footwear, commercial and } \\
\text { service industry }\end{array}$ & $\begin{array}{c}\text { High } \\
\text { (household and industrial effluents - heavy } \\
\text { metals - and PPA occupation by urban area) }\end{array}$ \\
\hline Lower & $\begin{array}{l}\text { Metal and mechanic, food, petrochemical } \\
\text { and service industry }\end{array}$ & $\begin{array}{c}\text { High } \\
\text { (household and industrial effluents - } \\
\text { heavy metals and bicarbonate - and PPA } \\
\text { occupation by urban area) }\end{array}$ \\
\hline
\end{tabular}

PPA - permanent preservation area. Source: Attorney General Office, state of Rio Grande do Sul - Division of Technical Assistance Luiz Fernando de Souza, biologist, 2008.

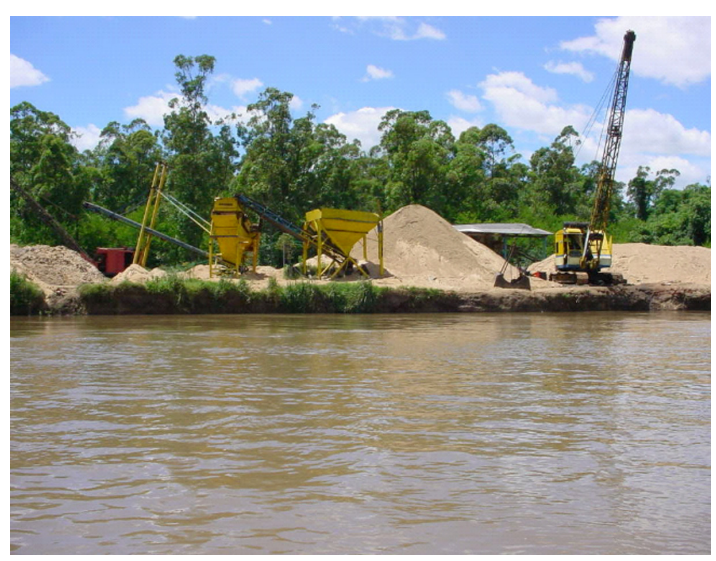

Figure 1. Sand removal. Source: Jackson Müller, biologist.

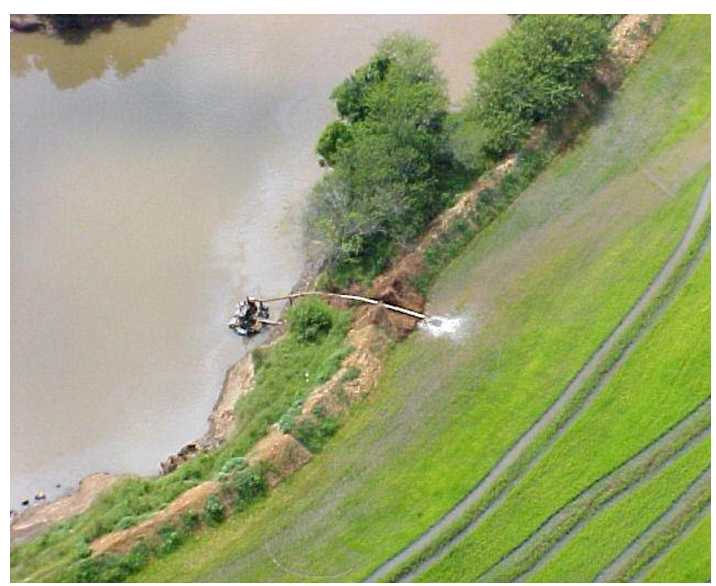

Figure 2. Dual environmental crime. Source: Jackson Müller, biologist.

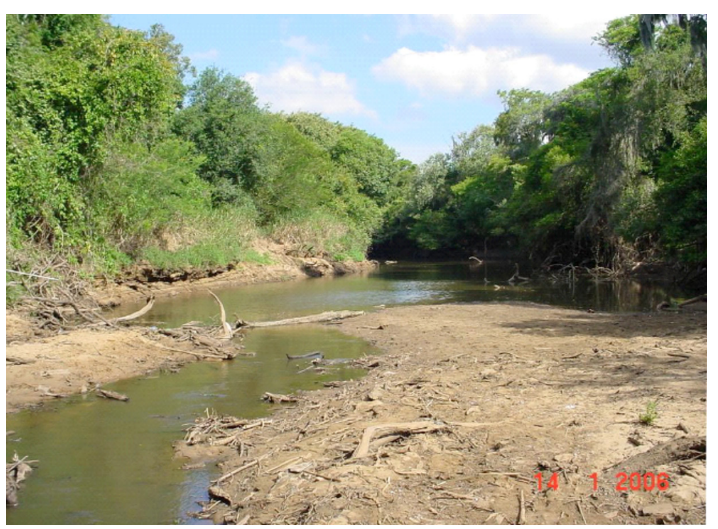

Figure 3. Sinos River (summer of 2005). Source: SOS Rio dos Sinos (2012).

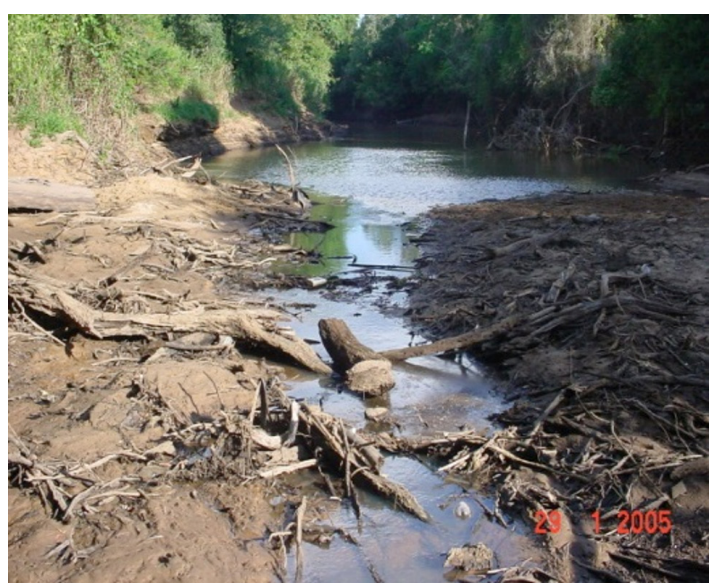

Figure 4. Sinos River (summer of 2006). Source: SOS Rio dos Sinos (2012). 


\section{The Government and the Environmental Fragilities of the Sinos River Basin}

Social, cultural and economic changes, particularly after the II World War, have challenged the environment in our society. We should evaluate the strategies applied in the past and the development of permanent and innovative public policies of environment management. This study analyzes how public offices in the Sinos River Basin establish mechanisms to manage environmental risks generated by industrialization and population growth in the cities in this region.

We have seen that the main objective action of the municipal government for the Sinos River Basin was the creation of the Pro-Sinos in 2007. An important action of regional planning, it may lead, in the long run, to a reduction in river pollution due to household wastewaters. However, the river agony results from several causes. The industrial and agricultural sectors contribute to river pollution significantly. Therefore, several interests are at stake, and the government should play the role of mediator.

The major conflict involving public environmental policies in the Sinos Valley arises from two facts. First, it is a consensus that the civil society should hold the government accountable for the lack of investment in industrialization, which may lead to stagnation or a reduction in the number of jobs. On the other hand, the development of industrialization, still closely associated with the leather and footwear industry in the Sinos Valley, eventually has a profound environmental impact. What should be done: keep and expand the industrialization system to avoid cutting jobs, or protect the ecological system? In this context, it is important to keep in mind that political parties have the purpose of holding on to power once they have acquired it. Therefore, electoral issues usually hold center stage, and although some politicians are more sensitive and aware of industrialization risks, they cannot act independently, without raising the protests of those that defend industrial development. Graph 1 shows that the environment is one of the major governmental concerns. The answers given by 56 members of municipal governments in the Sinos Valley (mayors, secretaries and municipal department officials) when asked about five investment priorities in the Sinos Valley are shown in the graph below ${ }^{9}$.

Although public officials understand the importance of the environment, the most significant choice for investments is employment. They may give priority to clean industries, but the region has been historically associated with the leather and footwear manufacture. Therefore, when these highly polluting companies attempted to invest in the Sinos Valley in the recent past, they faced very few constraints to their operation in the region.

Another survey conducted in our study shows that the technicians ( 35 people interviewed) that work in the

\footnotetext{
9 Data from the municipal governments in the Sinos Valley, as well as data provided by entrepreneurs and technicians, were collected for the Doctoral Thesis of João Alcione Sganderla Figueiredo (Figuriredo, 2008).
}

leather and footwear industry in the region perceive the need to invest in the environment. This was the third most frequent answer, after basic sanitation and health, in this order. These data very probably reflect the fact that those interviewed felt greater pressure from environmental problems, as they are often in contact with the control offices in the state. The difference lies in the fact that the expected pressure does not become a matter of concern for the tannery owners and managers (36 people in management positions answered the questionnaire), and they go on acting in accordance to market laws and the priority assigned to industrialization, rather than according to their concern with basic sanitation and employment. The Graph 2 below illustrates this reality.

These two graphs partially demonstrate the conflict of interest between government and private companies. Managers and company owners, supported by the Industry Federation of the State of Rio Grande do Sul (FIERGS, Federação da Indústria do Rio Grande do Sul), blame household wastewaters for contaminations, and exempt industrial effluents from deaths and pollution of the Sinos River. It is a "game" of "putting the blame on" others, which

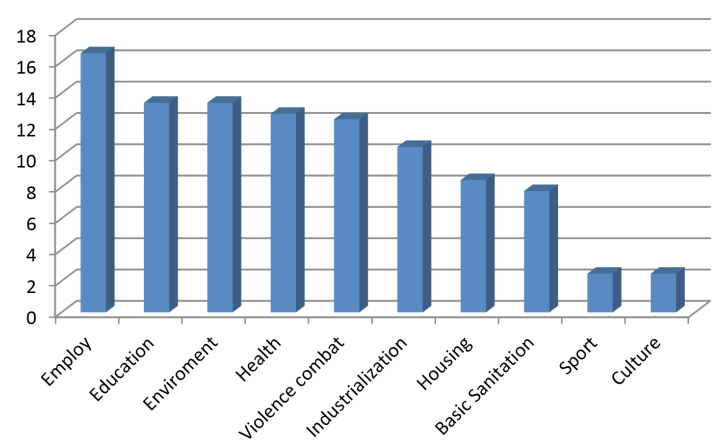

Graph 1. Investment priority - Government in Sinos Valley. Source: Prepared by the authors, 2012.

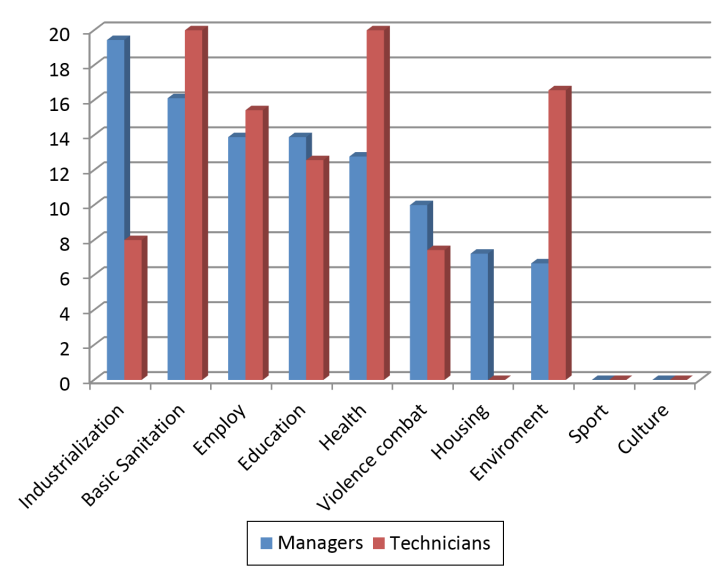

Graph 2. Investment priority - Managers and technicians in Sinos Valley companies. Source: Prepared by the authors, 2012. 
is also clear among governmental representatives, who, although they understand environmental needs and demands, classify basic sanitation, one of their responsibilities and fundamental to reduce river pollution, as one of the last investment priorities, as seen in the graph.

The sewerage network in the area of the Sinos River Basin is short and not prepared for wastewater treatment. Data for 2000 show that only $23.34 \%$ of the households are connected to the network, and only the wastewaters of $5 \%$ of these households are treated (IHU 2007). That is, most of the sewage collected goes directly into the river and its affluents without any treatment.

This only started to change in the middle of the first decade of the XXI century. On April 19, 2007, twelve of the 32 counties in the Sinos River Basin signed a Protocol of Intentions to establish the first Public Sanitation Group according to Law 11,107/2005 (Brasil, 2005) and Decree no. $6,017 / 2007$ (Brasil, 2007). Until then, sanitation in Brazil was carried out by private organizations established under civil law. On October 9, 2007, the Pro-Sinos Statute was approved, and by 2010, twenty-two counties had joined it. After the Pro-Sinos Committee was established and data were collected by the Sinos Committee, the Group submitted projects to the federal government to expand the sewage system and improve and expand the sewage treatment plants (STP).

From 2008 to 2010 , several actions, all funded by the federal government, were carried out by the Pro-Sinos Committee:

- Basic Sanitation Plan for the Sinos River Basin Sinos Plan;

- Regional Plan for the Integrated Management of Solid Wastes;

- Environmental Education Program - Collective Educators (Brasil, 2012b).

The plans listed above, submitted to the federal government, were important to define actions related to the sewerage network and sewage treatment, which we are interested in analyzing. Data of the 2010 basic sanitation census, shown in the Table 2 below, suggest that municipal governments seem to be concerned with this issue. Those actions obviously echoed in the federal government, and funds from the Growth Acceleration Plan (PAC, Plano de Aceleração do Crescimento) were assigned to those projects.

The data collected show that, in the last three years, there was an increase of $7 \%$ in the sewerage network of the Sinos River Basin and of practically $2 \%$ in wastewater treatment. Total numbers show that the network covered $29.9 \%$ of the Sinos Valley up to 2010 , and that $6.9 \%$ of this total was treated. According to information provided by the city halls in the area, some important cities will reach $50 \%$ of wastewater treatment by 2013 , as is the case of Novo Hamburgo, where only $2.3 \%$ of wastewaters were treated up to 2010 . These improvements will be the result of the Pro-Sinos Consortium projects funded by PAC money.

Such changes will certainly have important environmental consequences in the near future. However, according to the Sinos Committee data for 2000 , about $70 \%$ of the population in the basin area had only local and precarious drainage solutions, whereas $25 \%$ of the households did not have any type of wastewater disposal system. Even if these numbers are better now, they might still be impressive. A significant amount of household wastewaters may still flow directly into the river or its affluents. In face of this condition and considering the expected population growth until at least 2020, it is reasonable to question whether the sewage system and treatment network, although expanded, will be enough. Unless cities promote and control other solutions to make up for the historic deficit in this area, the expected environmental impact of the latest governmental measures is below what is necessary to reverse the pollution caused by household wastewaters (Brasil, 2012b).

Another example of this "buck-passing" is found in the struggle between city halls and the Environmental Protection State Foundation (FEPAM, Fundação Estadual de Proteção Ambiental). The Brazilian Classification of Economic Activities (CNAE, Classificação Nacional de Atividades Econômicas) assigned a level of high potential pollution to tanning plants, and the environmental licenses to build a tanning plant should be granted by FEPAM. The cities use this fact to assign the responsibility for environmental control to FEPAM. Some municipal government officials claimed not to be responsible for fining these companies for infringements, as they believed that by doing so they would be extrapolating their responsibility and disregarding the authority of higher offices. The 2006 events raised a controversy between the two instances. Below is a fragment of an interview that illustrates the position of most governmental representatives and technical employees in the city halls:

[...] According to legislation, the responsibility to provide licenses for tanning plants is held by the State (FEPAM). According to FEPAM, no other company that generates solid waste can come to our city [...]. It should be made clear that before the environmental disaster there was no type of work or control, that is, there was nothing to be done, because the laws showed that FEPAM, and not us (city hall), we could not interfere in any way. (Public servant, 2008).

Rules established by FEPAM prohibit the installation of plants that discharge effluents into the Sinos River, which restricts the development of an industry with a high potential for environmental contamination. However, this initiative was taken after 2006, whereas the contamination risks in the basin had been visible and known since at least 2002, when there was another event of mass fish deaths. At least one question remains: As wastewater treatment is expanded and there is a possible reduction in the Sinos 
Table 2. Treated waste in 2010 in the Sinos River Basin in \%.

\begin{tabular}{|c|c|c|c|}
\hline City & \% population served & $\%$ sewage collected & \% wastewater treated \\
\hline \multicolumn{4}{|l|}{ Araricá: } \\
\hline Cachoeirinha: & 34.5 & 100 & 57.3 \\
\hline Campo Bom: & 0 & 0 & 0 \\
\hline Canela: & 13.8 & 100 & 16.8 \\
\hline Canoas: & 17.2 & 55 & 13.3 \\
\hline Capela de Santana: & 0 & 0 & 0 \\
\hline Caraá: & 0 & 0 & 0 \\
\hline Dois Irmãos: & 8.7 & 100 & 0 \\
\hline Estância Velha: & 3.3 & 100 & 5.1 \\
\hline Esteio: & 5.1 & 100 & 6.4 \\
\hline Glorinha: & 0 & 0 & 0 \\
\hline Gramado: & 21.8 & 100 & 27.2 \\
\hline Gravataí: & 22 & 100 & 50.8 \\
\hline Igrejinha: & 2.9 & 0 & 0 \\
\hline Ivoti: & 0 & 0 & 0 \\
\hline Nova Hartz: & 0 & 0 & 0 \\
\hline Nova Santa Rita: & 0 & 0 & 0 \\
\hline Novo Hamburgo: & 2.4 & 100 & $2.3 \%$ \\
\hline Osório: & 0 & 0 & 0 \\
\hline Parobé: & 0 & 0 & 0 \\
\hline Portão: & 0 & 0 & 0 \\
\hline Riozinho: & 0 & 0 & 0 \\
\hline Rolante: & 0 & 0 & 0 \\
\hline Santa Maria do Herval: & 0 & 0 & 0 \\
\hline $\begin{array}{l}\text { Santo Antônio da } \\
\text { Patrulha: }\end{array}$ & 0 & 0 & 0 \\
\hline São Francisco de Paula: & 0 & 0 & 0 \\
\hline São Leopoldo: & 27.6 & 100 & $33.20 \%$ \\
\hline São Sebastião do Caí: & 0 & 0 & 0 \\
\hline Sapiranga: & 0 & 0 & 0 \\
\hline Sapucaia do Sul: & 5.1 & 100 & 8.1 \\
\hline Taquara: & 0 & 0 & 0 \\
\hline Três Coroas: & 0 & 0 & 0 \\
\hline
\end{tabular}

Source: National Sanitation Information System (SNIS, Sistema Nacional de Informações sobre Saneamento) (Brasil, 2010).

River pollution, will the control over industries persist, or will there be some slackening due to buck-passing?

In any way, the economic growth of the Sinos Valley has followed industrial development patterns: production grows to increase profits and to ensure "adherence" to the international market. Such vision, held by governments and industries, obviously leads to an increase in environmental impacts.

At the same time, community participation is weak and social mobilization is not raised. Awareness of environmental risks was overshadowed by the risk posed to family survival, represented in a possible loss of employment.

As popular participation is not very significant, public environmental policies were defined primarily by the government, and were not the result of a broad community discussion. This only changed after the 2006 disaster, as seen in the words of a municipal government representative, reproduced below:
After the tragedy of the environmental crime, we started a political battle in an attempt to build a public instrument to conduct public policies in the Sinos River Basin. Today we have the Sinos Committee in the region [...]; this committee has conducted a number of extraordinary studies and research, it made a diagnosis of the Sinos River Basin. The problem is that those data were not put into practice, the works were never built based on those diagnoses because there were no agreements between the municipal, state and federal governments [...]. Therefore, after the tragedy [...] we had all the counties searching for a single integrative plan for the Sinos River. Today [...] we have three approved projects in the federal government, for investment in studies to plan integrated actions: environmental sanitation [...], solid waste treatment plan [...] and environmental education. (government official).

Although there is a Basin Committee with a major participation in making diagnoses and conducting studies, the material produced had not raised the interest of the 
municipal governments before the 2006 environmental tragedy. That is, up to that moment, the agenda of city halls had no room for the environmental issues that affected all. Up to that time, the identification of risks and the negotiations for an environmental policy were guided by the traditional principles of power. Governments should define a position about environmental policies, but they are also exposed to the conflict between economic, social and cultural factors (the industrial tradition of tanning plants and employment maintenance) and environmental issues. If society does not make demands, governments tend to assign secondary importance to environmental issues.

In face of such reality, we see that, in Brazil, civic concerns are generally weak, which promotes a childish attitude among citizens, dependent on our "gentle mother nation". There is, therefore, both a lack of governmental responsibility, and a lack of commitment by part of the civil society. These data are confirmed by a Greenpeace survey in the Brazilian context (Greenpace, 2012), which found that $53 \%$ of Brazilians claim that the federal government is responsible for environmental issues, whereas $29 \%$ believe that such responsibility lies with the state government. In contrast, $63 \%$ of those interviewed said not to have any interest, or to have little interest in ecology in Brazil.

Lopes (2006) draws attention to the growth of environmental discussions in Brazil in recent years, which has led to some unrest in certain sectors of the economy, particularly those that are "socially and environmentally harmful". According to the author, current conflicts are, in fact, updated versions of previous subversions disguised in a new language; in other words, we are facing an "environmentalization" of social conflicts.

In contrast, as the theme prevails and the movement advances, entrepreneurs themselves, the main producers of environmental degradation, also appropriate the criticism to their actions and try to use it to their advantage. Entrepreneurs divide into a pole of primitive environmental accumulation and a pole of critical appropriation, of "environmental responsibility" and direct their actions to a clean and environmentally correct production, together with the use of new materials and symbolic profits. Between these two poles are those that pragmatically use one or two elements characteristic of one of the two typical poles, as well as opposite ideals, as part of the strategies in their field of action. Workers and part of the population affected by environmental disasters also include environmental issues in their repertoire of interests and demands. (Lopes, 2006, p.32).

Although the "environmentalization" of social conflicts in contemporary Brazil has not had any significant impact on the development of public policies and popular participation, the growth of such debate in several social spheres, as well as the creation of representative environmental organizations that increasingly have the role of mediator in these conflicts, is undeniably important.

\section{Final Considerations}

The data presented here lead to at least three important and interconnected conclusions.

The first is that, in Brazil, despite all the efforts made in the last decade, data raised by academic studies still receive little attention from the government. In general, political logic sees academic studies as hurdles on the way to the success of their electoral objectives. We have seen the efforts made by the Sinos Committee to raise data since at least 1990. However, the interest in these intellectual assets by the government only emerged after the 2006 environmental disaster. Because of their electoral objectives, it took sixteen years and a dramatic environmental disaster to awaken public opinion and for local governments to take measures. It was only then that the cities in the region tried to work together and sought help in the knowledge produced in academic sciences. However, the river basin had already been giving signs of its ecological imbalance in fish deaths, droughts and floods.

Second: We remain attached to a clientelist political ethos and, therefore, have no vision of the future. The problem of the basin environment, as seen before, is not new. However, several municipal governments exempt themselves from responsibility, because it demands, as known, qualities such as political will and resources, and such efforts do not necessarily translate into votes. Therefore, in the best case scenario, the equation of Brazilian governments is reduced to satisfying what the "population" needs immediately from a clientelist point of view, disregarding systemic considerations. In sum, the development of the government/ citizen/businesspeople relationship is mediocre, as nobody demands from anybody the end of "advantages" acquired for the satisfaction of their own needs in favor of those of the biotic community as a whole, except in the case of maybe some NGOs, which, however, do not have the power to affect this destructive relationship.

Third: Typical of a society where civic culture is underdeveloped, the responsibility for problems, in this case environmental problems, lies with "others". Government, businesspeople and citizens blame each other mutually without, however, being capable of building feasible and rational alternatives for the general good. This restricted civic culture opens opportunities for, among other things, clientelism, a short term vision, and actions that favor individual rather than collective interests. Only recently have we tried some national long-term projects in some cities and states of Brazil, in addition to short-term governmental projects. Evidently, these projects have not yet become a prevalent practice that may lead us to a more republican and contemporary spirit.

\section{References}

Brasil, 2005. Lei $N^{o} 11.107$, de 6 de abril de 2005. Dispõe sobre normas gerais de contratação de consórcios públicos e dá outras providências. Diário Oficial da União, Brasília, 7 apr. 
Brasil, 2007. Decreto $N^{\circ}$ 6.017, de 17 de janeiro de 2007. Regulamenta a Lei no 11.107, de 6 de abril de 2005, que dispõe sobre normas gerais de contratação de consórcios públicos. Diário Oficial da União, Brasília, 18 jan.

Brasil. Ministério das Cidades, 2010. Sistema Nacional de Informações sobre Saneamento - SNIS. Brasília: Ministério das Cidades. Available from: $<$ http://www.snis.gov.br/>. Access in: 10 Apr. 2012.

Brasil. Ministério do Meio Ambiente, 2012a. Conselho Nacional do Meio Ambiente - CONAMA. Brasilia: CONAMA. Available from: <http://www.mma.gov.br/port/conama $>$. Access in: 05 May. 2012

Brasil. Ministério do Meio Ambiente, 2012b. Portal Programa de Educação Ambiental PRÓ-SINOS - consórcio. PRÓ-SINOS. Available from: <http://www.portalprosinos.com.br/conteudo. php?id=consorcio $>$. Access in: 05 May 2012.

CÁNEPA, EM and GRASSI, LAT., 2001. Os Comitês de Bacia no Rio Grande do Sul - uma experiência histórica. Porto Alegre: ABES. Available from: <http://www.abes-rs.org.br/rechid/ comites-1.htm>. Access in: 05 Jun. 2012.

COSTA, AB and PASSOS, MC. (Eds.), 2004. A indústria calçadista no Rio Grande do Sul. São Leopoldo: Editora Unisinos.

DREHER, MN., 1989. A história da Igreja Evangélica de confissão luterana no Brasil. In Brakemeier, G., (Ed.). Presença luterana: 1990. São Leopoldo: Sinodal. p. 93-104.

FIGUEIREDO, JAS., 2008. ¿Indiferencia o necesidades insatisfechas? La cuestión del riesgo tecnológico en "Vale do Rio do Sinos". Madrid: Universidad Complutense de Madrid.

Greenpace, 2012. Available from: <http://www.greenpeace. blogtvbrasil.com.br/>. Access in: 2012 May 08.

HUNSCHE, CH., 1975. O Biênio 1824/25 da imigração e colonização alemã no Rio Grande do Sul. Porto Alegre: A Nação.

Instituto Humanas Unisinos - IHU, 2007. O Rio dos Sinos vive a era das conseqüencias. As meias medidas não bastam mais. São Leopoldo: Unisinos. Available from: <http://projeto.unisinos.br/ ihu/uploads/publicacoes/edicoes/1194291145.1pdf.pdf $>$. Access in: 10 Apr. 2012.

Instituto Humanas Unisinos - IHU, 2012. 74,89\% da região do Vale do Sinos necessita do seu rio para viver. Unisinos. Available from: <http://www.ihu.unisinos.br/noticias/507849-7489-daregiao-do-vale-do-sinos-necessita-do-rio-dos-sinos-pra-viver>. Access in: 12 Apr. 2012.
Jornal VS, 2012. Rio dos Sinos atinge o menor nivel em 10 anos: régua marca $45 \mathrm{~cm}$. São Leopoldo: Jornal VS. Available from: $<$ www.jornalvs.com.br/meio-ambiente/166060/rio-dos-sinosatinge-o-menor-nivel-em-10-anos-regua-marca-45-cm.html $>$. Access in: 08 May 2012.

KAYSER, A., 2011. A idade do rio do sinos. In KAYSER, A. (Ed.). Arno Kayser-pra pensar a ecologia em dias tão confusos. Available from: $<$ https://arnokayser.wordpress.com/2011/11/19/aidade-do-rio-do-sinos/>. Access in: 10 Apr. 2012.

LOPES, JSL., 2006. Sobre processos de "ambientalização" dos conflitos e sobre dilemas da participação. Horizontes Antropológicos, vol. 12, no. 25, p. 31-64. http://dx.doi.org/10.1590/ S0104-71832006000100003.

MENDONÇA, AG and VELASQUES FILHO, P., 1990. Introdução ao Protestantismo no Brasil. São Paulo: Loyola.

Novo Hamburgo. Companhia Municipal de Sanenamento COMUSA, 2012. Socioambiental. Novo Hamburgo: COMUSA. Available from: <http://www.comusa.rs.gov.br/index.php/ meioAmbiente>. Access in: 05 May. 2012.

NUNES, MF., 2009. "O Negro no Mundo Alemão": cidade, memória e ações afirmativas no tempo da globalização. Florianópolis: Universidade Federal de Santa Catarina. Doctoral thesis in Social anthropology.

NUNES, MF., ROCHA, ALC., MAGALHÃES, ML., and KUHN JUNIOR, N., 2013. Era um hino de fábrica apitando": a memória do trabalho negro na cidade de Novo Hamburgo (RS), Brasil. Etnográfica, vol. 17, no. 2, p. 269-291. Available from: <http:// etnografica.revues.org/3122>. Access in: 18 Jun. 2015.

PORTER, ME., 1989. A Vantagem Competitiva das Nações. Rio Janeiro: Campus.

PORTO, A., 1934. O trabalho alemão no Rio Grande do Sul. Porto Alegre: Editora e Gráfica Terezinha.

Rio Grande do Sul. Fundação Estadual de Proteção Ambiental FEPAM, 2012a. Qualidade das águas da bacia hidrográfica do Rio dos Sinos. FEPAM. Available from: <http://www.fepam.rs.gov.br/ qualidade/qualidade_sinos/sinos.asp $>$. Access in: 10 May 2012.

Rio Grande do Sul, 2012b. Fundação de Economia e Estatística - FEE. Porto Alegre: FEE. Availabre from: <http://www.fee. rs.gov.br/>. Access in: 10 Mar. 2012.

SOS Rio dos Sinos, 2012. Movimento ecológico SOS Rio dos Sinos. SOS Rio dos Sinos. Availabre from: < http://www.sosriodossinos. org.br/>. Access in: 05 May 2012.

2008 